\title{
PENGARUH MODEL PEMBELAJARAN PREDICT-OBSERVE-EXPLAIN (POE) TERHADAP PEMAHAMAN KONSEP SISWA MATERI KESETIMBANGAN KELARUTAN KELAS XI MIA SMAN 2 LABUAPI TAHUN AJARAN 2017/2018 \\ A.Alhanaen As Suhaesa', Yayuk Andayani', Muti'ah Muti'ah', Yunita Arian Sani Anwar ${ }^{2}$ \\ ${ }^{1}$ Mahasiswa Prodi Pendidikan Kimia, Universitas Mataram \\ ${ }^{2}$ Dosen Prodi Kimia, Universitas Mataram \\ Program Studi Pendidikan Kimia Fakultas Keguruan dan Ilmu Pendidikan Universitas Mataram \\ Keperluan korespondensi, email: ahmadsuhaesa1996@gmail.com
}

\begin{abstract}
Abstrak
Penelitian ini bertujuan untuk mengetahui ada atau tidaknya pengaruh model pembelajaran Predict-Observe-Explain (POE)terhadap pemahaman konsep siswa materi kesetimbangan kelarutan kelas XI MIA SMAN 2 Labuapi tahun ajaran 2017/2018. Jenis penelitian yang digunakan berupa penelitian eksperimen semu dengan desain penelitian Nonequivalent Control Group Design. Populasi dalam penelitian ini adalah seluruh siswa kelas XI MIA SMAN 2 Labuapi. Sampel dalam penelitian ini yaitu kelas XI MIA 1 dan XI MIA 2 yang ditentukan melalui teknik pengambilan sampel jenuh. Variabel bebas dalam penelitian ini adalah model pembelajaran Predict-Observe-Explain (POE)untuk kelas eksperimen dan model pembelajaran konvensional untuk kelas kontrol. Variabel terikatnya adalah pemahaman konsep siswa dalam materi kesetimbangan kelarutan. Teknik pengumpulan data dilakukan dengan pemberian pretest dan posttest dalam bentuk tes uraian untuk mengukur pemahaman konsep siswa. Pengujian hipotesis dilakukan dengan menggunakan Gain uji-t dengan pengambilan keputusan didasarkan pada uji hipotesis satu pihak (uji pihak kanan). Gain uji-t digunakan untuk menganalisis data pemahaman konsep siswa, didapatkan $t_{\text {hitung }}(1,35)<t_{\text {tabel }}(2,021)$. Hasil tersebut menunjukkan bahwa model pembelajaran Predict-Observe-Explain (POE) tidak berpengaruh terhadap pemahaman konsep siswa materi kesetimbangan kelarutan kelas XI MIA SMAN 2 Labuapi tahun ajaran 2017/2018.
\end{abstract}

Kata Kunci:Model pembelajaran Predict-Observe-Explain (POE), Pemahaman Konsep, Kesetimbangan Kelarutan.

\section{THE EFFECT OF PREDICT-OBSERVE-EXPLAIN (POE) LEARNING MODELS ON UNDERSTANDING OF STUDENTS CONCEPT OF SOLUBILITY EQUILIBRIUM MATERIAL CLASS XI MIA SMAN 2 LABUAPI 2017/2018}

\begin{abstract}
This study aim to determine the effect of Predict-Observe-Explain (POE) learning models on understanding of students concept of equilibrium material of class XI MIA SMAN 2 Labuapi 2017/2018. The type of research used was a quasi-experimental research design Nonequivalent Control Group Design. The population in this study were all class students of XI MIA SMAN 2 Labuapi. The sample in this study is XI MIA 1 and XI MIA 2 which is determine by saturated sample technique. The independent variable in this study is Predict-Observe-Explain (POE) learning models for experimental class and conventional learning models for control class. The dependent variable is the understanding of student concept in the solubility equilibrium material. Data collection techniques were carried out by giving pretest and posttest in the form of a description test to measure
\end{abstract}


students understanding concept. Hypothesis testing is done by using the Gain t-test with decision making based on the on-party hypothesis test (right-hand test). Gain t-test is used to analyze the data of studentsconcept understanding, it is obtained $t_{\text {count }}(1,35)<t_{\text {table }}(2,202)$. The result indicate that the POE learning models does not affect the understanding of student concept of solubility equilibrium material of Class XI MIA SMAN 2 Labuapi 2017/2018.

Keywords: Predict-Observe-Explain (POE) Learning Models, Understanding of Concept, Solubility Equilibrium.

\section{PENDAHULUAN}

Berbagai permasalahan menyangkut masa depan pendidikan kita terus menuai perdebatan yang tak kunjung selesai, bahkan seolah-olah memberikan tekanan bagi kalangan pendidik. Berbagai upaya yang telah dilakukan pemerintah dalam upaya peningkatan kualitas pendidikan, diantaranya pengalokasian dana pendidikan, pemberian tunjangan sertifikasi bagi para guru, sampai pada perubahan sistem pendidikan. Upaya tersebut diharapkan akan dapat memberikan jaminan ideal akan tercapainya tujuan pendidikan secara holistis dan menyeluruh (Widiadnyana, 2014).

Kimia adalah mata pelajaran yang masih dianggap sulit oleh sebagian besar siswa tingkat sekolah menengah atas bahkan perguruan tinggi. Anggapan ini mungkin tidak berlebihan selain mempunyai sifat yang abstrak, kimia juga memerlukan pemahamn konsep yang baik, karena untuk memahami konsep yang baru diperlukan prasyarat pemahaman konsep sebelumnya. Pemahaman konsep kimia sangat penting bagi siswa, karena konsep kimia yang satu dengan yang lainnya memiliki keterkaitan sehingga mempelajarinya harus runtut dan berkesinambungan. Jika siswa telah memahami konsep-konsep kimia, maka akan memudahkan siswa dalam memahami konsep-konsep kimia berikutnya yang lebih kompleks (Winarti, 2001; Mubshirah, dkk., 2018).

Hasil ujian akhir semester I mata pelajaran kimia kelas XI MIA SMAN 2 Labuapi Tahun Ajaran 2017/2018 menunjukan hasil belajar yang kurang memuaskan bagi sebagian besar siswa. Hal ini mungkin disebabkan karena masih rendahnya pemahaman konsep siswa terkait materi pelajaran. Selain itu siswa cendrung menghafal beberapa contoh soal yang dijelaskan oleh guru sehingga jika diberikan soal yang berbeda, maka siswa merasa kesulitan dalam menjawab dan hasil belajar menjadi kurang memuaskan.
Tabel 1. Nilai Rata-Rata Ulangan Akhir Semester Kimia

\begin{tabular}{ccc}
\hline Kelas & $\begin{array}{c}\text { Jumlah } \\
\text { siswa }\end{array}$ & Nilai rata-rata \\
\hline XI MIA 1 & 26 & 55.19 \\
XI MIA 2 & 26 & 52.32 \\
\hline
\end{tabular}

(Sumber: Arsip Guru Kimia Kelas XI MIA SMAN 2 Labuapi Tahun Ajaran 2017/2018).

Berdasarkan nilai rata-rata ulangan akhir semester tersebut, telah jelas bahwa perlu adanya tindakan untuk mengatasinya, yaitu guru harus mampu melakukan proses pembelajaran dengan lebih baik, bahkan melakukan inovasi. Menurut Sa'ud (2011), inovasi adalah sesuatu perubahan yang baru, berbeda dari hal yang sebelumnya, jauh lebih baik dan dilakukan dengan sengaja yang bertujuan untuk meningkatkan kemampuan serta mencapai tujuan tertentu. Ada berbagai cara untuk melakukan inovasi dalam pendidikan, misalnya saja dengan menerapkan model, media, metode, strategi, bahkan pendekatan pembelajaran yang bertujuan agar pembelajaran lebih menarik dan tidak terasa membosankan bagi peserta didik.

Salah satu model pembelajaran yang dapat digunakan adalah model pembelajaran Predict-Observe-Explain (POE).Model pembelajaran Predict-Observe-Explain (POE) merupakan suatu model yang efisien untuk menciptakan diskusi para siswa mengenai konsep ilmu pengetahuan. Model pembelajaran Predict-Observe-Explain (POE) melibatkan siswa dalam meramalkan suatu fenomena, melakukan observasi melalui demonstrasi atau eksperimen, dan akhirnya menjelaskan hasil demonstrasi dan ramalan mereka sebelumnya. Kemampuan Predict-Observe-Explain (POE) dapat menyelidiki gagasan siswa dan cara mereka dalam menerapkan pengetahuan pada keadaan yang sebenarnya (praktikum) (Liew, 2004). 


\section{Chemistry Education Practice,1 (2), 2018 - 29}

Suhaesa, Andayani, Muti'ah, Anwar

Model pembelajaran Predict-ObserveExplain (POE) sangat efektif untuk menghasilkan perubahan konsep. Guru dapat menerapkan pembelajaran Predict-ObserveExplain (POE) di kelas. Siswa akan terbantu untuk menghindari terjadinya miskonsepsi yang sering terjadi saat transfer ilmu berlangsung. Siswa akan terus menggali keingintahuannya terhadap suatu konsep yang diberikan oleh guru, dan pembuktian-pembuktian gagasan tersebut dapat dilakukan dengan melakukan pengamatan atau observasi langsung (Nuramelia, 2016).

Menurut Juniati dalam Nuramelia (2016) tiga elemen metode pembelajaran Predict-Observe-Explain (POE) adalah (1) membuat prediksi (predict), dan tujuannya adalah untuk memungkinkan guru bersama peserta didik memahami apa yang sedang dipikirkan. Diharapkan ada kesesuaian antara apa yang dipikirkan guru dengan apa yang dipikirkan peserta didik. Pemahaman peserta didik tentang situasi yang dihadapi bisa merentang sangat luas dan akan muncul dalam diskusi. Kegiatan pengamatan dimulai dengan guru menunjukkan atau mendemonstrasikan suatu fenomena lalu mengubah satu faktor dalam fenomena itu dan meminta peserta didik untuk memprediksi apa yang akan terjadi. (2) Melakukan pengamatan (observe), kegiatan pengamatan dapat dilakukan terhadap demonstrasi guru atau berupa kegiatan peserta didik (eksperimen). Guru harus meyakinkan peserta didik untuk melakukan pengamatan dengan teliti dan mendiskusikan hasil pengamatannya dengan kelompoknya. Peserta didik melakukan eksperimen lalu mengamati dan mencatat pengamatannya dan jika perlu mengulang eksperimennya dan guru memeriksa pengamatan peserta didik. (3) Membuat penjelasan (explain), ini adalah tahap akhir dari metode pembelajaran Predict-Observe-Explain (POE). Pada tahap ini peserta didik mendiskusikan prediksi dan hasil pengamatan yang telah dilakukan. Biasanya ini bukan tugas yang mudah, hal ini disebabkan oleh komitmen dalam mengubah pemahaman peserta didik terhadap konsep-konsep sains yang ada.

Pemahaman menurut Bloom dalam Subiyanto (1988) diartikan sebagai kemampuan untuk menyerap arti dari materi atau bahan yang dipelajari. Konsep adalah ide abstrak yang dapat digunakan untuk menggolongkan atau mengklasifikasikan sekumpulan objek. Indikator pemahaman konsep yang diamati pada tes tertulis ada 3 indikator pemahaman yaitu : (1)
Translasi yaitu kemampuan untuk memahami suatu gagasan dan dapat disampaikan dengan menggunakan metode yang berbeda dari proses yang dicapai atau dari pernyataan asal dari apa yang telah didapatkan. Secara sederhana translasi adalah kemampuan untuk menerjemahkan suatu konsep ke bahasa yang dipahami sendiri kemudian ditunjukan dengan menyampaikan dalam bentuk lain berupa model atau simbol yang digunakan. (2) Interpolasi yaitu kemampuan untuk mengembangkan dan mendapatkan informasi yang tidak tercantum secara ekplisit dari sumber yang dirujuk. Satu tingkat lebih tinggi dari translasi yang hanya mengubah informasi yang didapatkan ke dalam bentuk lain, maka interpolasi mampu memberikan lebih dari yang tertuang secara eksplisit dan disampaikan. (3) Ekstrapolasi yaitu kemampuan untuk meramalkan (menduga) atau memberikan gambaran akan sesuatu hal berdasarkan trend yang muncul pada data. Halhal yang diramalkan dapat berupa konsekuensi, implikasi dan akibat yang akan muncul berdasarkan motif dan pola-pola yang ada pada data. Hal ini berarti ektrapolasi lebih dari sekedar pemahaman mengenai hal-hal yang kongkret dan abstrak dari data yang didapatkan.

\section{METODOLOGI PENELITIAN}

Penelitian ini dilaksanakan di SMA Negeri 2 labuapi pada bulan April sampai dengan Mei tahun ajaran 2017/2018. Jumlah popolasi yaitu seluruh siswa kelas XI MIA sebanyak 48 orang. Sampel dalam penelitian ini yaitu siswa kelas XI MIA 1 berjumlah 25 orang dan siswa kelas XI MIA 2 berjumlah 23 orang. Teknik pengambilan sampel (sampling) yang digunakan dalampenelitian ini adalah teknik nonprobability sampling, yaitu sampling jenuh.Teknik nonprobability sampling adalah teknik pengambilan sampel yang tidak memberipeluang/kesempatan sama bagi setiap unsur atau anggota populasi untuk dipilihmenjadi sampel. Sedangkan sampling jenuh adalah teknik penentuan sampel bila semua anggota populasi digunakan sebagai sampel (Sugiyono, 2014).

Jenis penelitian yang digunakan yaitu quasi experimental design. Quasi experimental design atau rancangan eksperimental semu yaitu desain yang dapat mengontrol sumber-sumber non-validitas yang dapat mempengaruhi variabel penelitian (Darmadi, 2011). Desain penelitian yang digunakan yaitu nonequivalen control 
group design atau sama dengan pretest-posttest control group design, dimana dalam desain penelitian ini kelompok eksperimen atau kelompok kontrol tidak dipiih secara acak atau random.

Variabel penelitian adalah segala sesuatu yang berbentuk apa saja yang ditetapkan oleh peneliti untuk dipelajari sehingga diperoleh informasi tentang hal tersebut, kemudian ditarik kesimpulannya (Sugiyono, 2014). Dalam penelitian ini terdapat dua variabel yakni variabel penyebab atau variabel bebas dan variabel akibat atau variabel terikat. Variabel bebasnya adalah model pembelajaran PredictObserve-Explain (POE), sedangkan variabel terikat adalah pemahaman konsepsiswa tentang kesetimbangan kelarutan.

Penelitian inimenggunakan instrumen tes kemampuan pemahaman konsep berbentuk soal uraian dengan 3 indikator yaitu kemampuan pemahaman konsep translasi (mengungkapkan kembali suatu konsep dengan bahasa sendiri), kemampuan pemahaman konsep interpolasi (menghubungkan konsep satu dengan yang lainnya), kemampuan pemahaman konsep interpolasi (memprediksi konsep atau fenomena berikutnya berdasarkan trend data yang muncul). Instrumen yang sudah disusun terlebih dahulu diuji tingkat kevalidannya dengan uji validitas isi menggunakan ststistik Aiken's V dan validitas butir soal menggunakan formula product moment. Untuk menguji reliabilitas instrumen penelitian digunakan formula Alpha Cronbach's (a). Uji hipotesis dalam penelitian ini menggunakan Gain uji-t. Uji hipotesis dilakukan setelah data dianalisis dengan uji normalitas dan uji homogenitasnya terlebih dahulu(Sugiyono, 2014).

\section{HASIL DAN PEMBAHASAN}

Penelitian ini difokuskan untuk mengetahui pengaruh model pembelajaranPredict-Observe-Explain (POE) terhadap pemahaman konsep siswa dalam ranah kognitif. Kemampuan pemahaman konsep kesetimbangan kelarutan siswa pada penelitian ini berdasarkan pada tiga indikator, yaitu translasi, interpolasi dan ekstrapolasi. Data nilai rata-rata pemahaman konsep kedua kelas disajikan berikut :

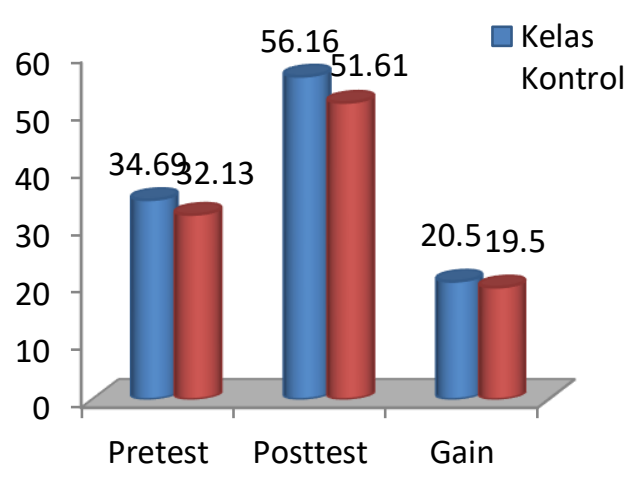

Gambar 1. Hasil Pemahaman Konsep Siswa

\section{Kelas Eksperimen}

Kelas eksperimen pada penelitian ini diterapkan model pembelajaran PredictObserve-Explain (POE) telah dilaksanakan sesuai tahapan yang ada, dengan penilaian keterlaksanaan observer terhadap peneliti pada setiap pertemuan. Menurut Suparno (2007), model pembelajaran Predict-Observe-Explain (POE) terdiri dari 3 tahapan yaitu predict (prediksi), observe (observasi), explain (menjelaskan). Penerapan model pembelajaran Predict-Observe-Explain (POE) tidak berpengaruh terhadap pemahaman konsep kesetimbangan kelarutan dibandingkan dengan menggunakan model pembelajaran langsung (ceramah, diskusi dan tanya jawab). Pada proses pelaksanaan di kedua kelas, peneliti sudah berusaha melaksanakan semua tahapan-tahapan yang disusun dalam rencana pelaksanaan pembelajaran. Adapun hasil skor kemampuan pemahaman konsep kesetimbangan kelarutan siswa berdasarkan indikator kemampuan pemahaman konsep dapat dilihat berikut ini:

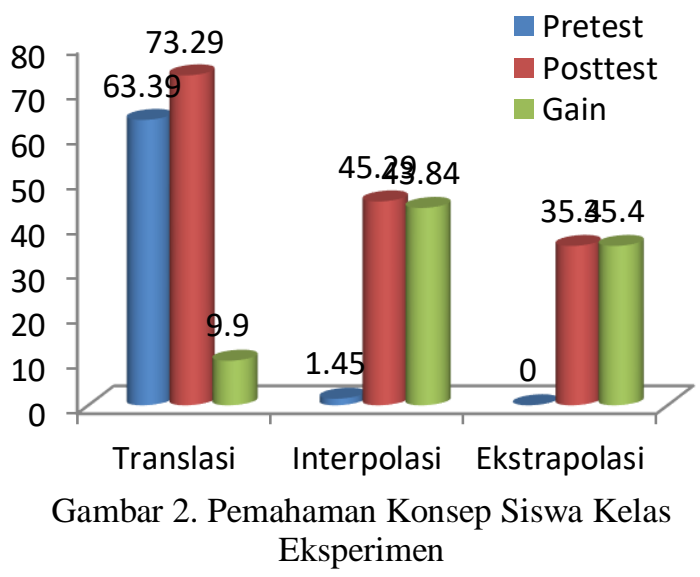

Pemahaman konsep tingkat translasi adalah kemampuan untuk memahami suatu gagasan dan dapat disampaikan dengan menggunakan metode yang berbeda dari proses yang dicapai atau dari pernyataan asal dari apa 


\section{Chemistry Education Practice,1 (2), 2018 - 31}

Suhaesa, Andayani, Muti'ah, Anwar

yang telah didapatkan. Secara sederhana translasi menurut Bloom dalam Subiyanto (1988) adalah kemampuan untuk menerjemahkan suatu konsep ke bahasa yang dipahami sendiri kemudian ditunjukan dengan menyampaikan dalam bentuk lain berupa model atau simbol yang digunakan. Indikator pemahaman konsep tingkat translasi pada penelitian ini diwakili oleh submateri kelarutan dan hasil kali kelarutan (pertemuan pertama), dan pemanfaatan kesetimbangan kelarutan dalam kehidupan sehari-hari (pertemuan kelima). Pemahaman konsep tingkat translasi ini mengalami peningkatan dari hasil pretest 63,39 $\%$ (kategori tinggi) menjadi 73,29\% (kategori tinggi) setelah penerapan pembelajaran dikelas (posttest).

Tahap Predict (Prediksi) dalam pembelajaran ini, siswa diberikan kesempatan untuk memprediksi tentang definisi kelarutan dan hasil kali kelarutan(pertemuan pertama), dan pemanfaatan konsep kesetimbangan dalam kehidupan sehari-hari (pertemuan kelima), selain itu siswa juga mengemukakan alasan prediksinya. Menurut Ozdemir (2011) tahap ini dapat digunakan untuk menggali pengetahuan awal siswa, memberikan informasi kepada guru mengenai kemampuan berpikir siswa, mengkondisikan siswa untuk melakukan diskusi, memotivasi siswa untuk mengeksplorasi konsep yang dimiliki, dan membangkitkan siswa untuk melakukan investigasi.Awalnya siswa mengalami kesulitan, sehingga perlu bantuan peneliti dalam mebuat prediksi, namun setelah beberapa pertemuan, siswa mulai terbiasa. Tahap selanjutnya yaitu Observe yaitu membuktikan prediksinya dengan dengan mengekspelore pengetahuan dasar kognitifnya. Tahapan ini menjadi sangat penting dalam pembelajaran karena melibatkan proses pengamatan obyek atau fenomena (Husain, dkk., 2013). Pada tahap ini siswa dibimbing oleh peneliti untuk melakukan praktikum mengenai konsep dasar kelarutan, jumlah maksimum zat yang dapat larut dalam suatu pelarut serta faktorfaktor yang memengaruhi kelarutan tersebut (pertemuan pertama), dan melakukan kajian literasi (pertemuan kelima).

Umumnya pada tahap ini, siswa mengalami beberapa kendala seperti belum bisa menggunakan alat dan bahan praktikum, dan ketersediaan buku belajar sehingga menghambat proses kajian literasi siswa. Masalah-masalah yang dihadapi dalam tahap observe ini menjadi kelemahan dalam model pembelajaran Predict-
Obseve-Explain (POE) seperti yang diungkapkan oleh Yupani, dkk (2013) memerlukan persiapan yang lebih matang dan waktu yang diperlukan karena biasanya waktu yang dibutuhkan lebih banyak.Selanjutnya tahap Explain yaitu menjalaskan hasil pada tahap observasi (praktikum) yang sudah dilaksanakan dan membandingkan hasilnya dengan prediksi awal siswa, apakah sesuai atau tidak. Karena keterbatasan waktu dan jam pelajaran terakhir, hanya terdapat satu kelompok saja yang menjelaskan hasil observasinya.

Interpolasi adalah kemampuan untuk mengembangkan dan mendapatkan informasi yang tidak tercantum secara ekplisit dari sumber yang dirujuk. Satu tingkat lebih tinggi dari translasi yang hanya mengubah informasi yang didapatkan ke dalam bentuk lain, maka interpolasi mampu memberikan lebih dari yang tertuang secara eksplisit dan disampaikan (Bloom dalam Subiyanto (1988)). Pada materi kesetimbangan kelarutan, indikator pemahaman konsep tingkat interpolasi terdapat pada perhitungan besarnya kelarutan dan hasil kali kelarutan (pertemuan kedua), pengaruh ion sejenis dan penambahan $p h$ (pertemuan ketiga). Pemahaman konsep tingkat interpolasi ini mengalami peningkatan dari hasil pretest $1,45 \%$ (kategori sangat rendah) menjadi 45,29\% (kategori sedang) setelah penerapan pembelajaran di kelas (posttest). Peningkatan ini tidak lebih baik dibandingkan dengan hasil pada kelas kontrol.

Tahap predict (prediksi) dalam pembelajaran ini, siswa diberikan kesempatan untuk memprediksi tentang reaksi suatu pelarutan (pertemuan kedua) dan prediksi bagaimana pengaruh penambahan ion senama terhadap kelarutan suatu zat (pertemuan ketiga). pada tahap ini, sebagian besar siswa masih belum bisa mentukan hasil suatu reaksi. Hal ini suatu kesalahan yang sangat vatal mengingat reaksi kimia adalah inti dari pelajaran kimia. Apabila siswa tidak bisa menuliskan reaksi kimia yang setara dan benar, dapat dipastikan ia akan mengalami kesulitan dalam mempelajari kimia. Sehingga peneliti mengulang kembali tentang reaksi kimia dan cara menuliskannya dengan benar. Tahap selanjutnya melakukan pengamatan (observe) berupa praktikum (pertemuan kedua) dan kajian literasi (pertemuan ketiga). Peserta didik melakukan eksperimen lalu mengamati dan mencatat pengamatannya. percobaan (eksperimen) pada tahap observe, pembelajaran terjadi by do 


\section{Chemistry Education Practice,1 (2), 2018 - 32}

Suhaesa, Andayani, Muti'ah, Anwar

science yang melibatkan siswa secara langsung dengan mengaktualisasikan diri ke dalam pengalaman nyata. Siswa akan belajar sebaikbaiknya dengan mengalami sendiri segala sesuatu, (we learn best by experiencing things for ourselves) (Suyono dan Hariyanto, 2012). Pada pecobaan kali ini berjaan lebih baik dibandingkan dengan percobaan saat pertemuan sebelumnya. Siswa sudah bisa menggunakan peralatan laboratorium dengan cukup baik. Namun saat menganlisis hasil percobaan dan menuliskan reaksi yang terjadi, siswa mengalami kesulitan sehingga peran peneiti dalam membimbing siswa sangat diperlukan. Selanjutnya tahap explain yaitu menjalaskan hasil pada tahap observasi (praktikum) yang sudah dilaksanakan dan membandingkan hasilnya dengan prediksi awal siswa, apakah sesuai atau tidak. Karena keterbatasan waktu dan jam pelajaran terakhir, hanya terdapat satu kelompok saja yang menjelaskan hasil praktikumnya.

Ekstrapolasi adalah kemampuan untuk meramalkan (menduga) atau memberikan gambaran akan sesuatu hal berdasarkan trend yang muncul pada data. Hal-hal yang diramalkan dapat berupa konsekuensi, implikasi dan akibat yang akan muncul berdasarkan motif dan pola-pola yang ada pada data. Hal ini berarti ektrapolasi lebih dari sekedar pemahaman mengenai hal-hal yang kongkret dan abstrak dari data yang didapatkan (Bloom dalam Subiyanto (1988). Indikator pemahaman konsep tingkat ektrapolasi diwakili oleh indikator memprediksi terbentuknya endapan dari suatu reaksi kesetimbangan (pertemuan keempat). Pemahaman konsep tingkat ekstrapolasi ini mengalami peningkatan dari hasil pretest $0 \%$ (kategori sangat rendah) menjadi $35,40 \%$ (kategori rendah) setelah penerapan pembelajaran di kelas (posttest). Hal ini disebabkan karena siswa tidak mengetahui sama sekali tentang terbentuknya endapan pada saat pretest sehingga ketika posttest terlihat peningkatan namun tidak secara signifikan, bahkan peningkatan ini tidak lebih baik dibandingkan dengan hasil pada kelas kontrol.

Tahap predict (prediksi), siswa diberikan kesempatan untuk memprediksi tentang pengaruh ion senama berupa terbentuknya endapan selain itu siswa juga mengemukakan alasan prediksinya, sedangkan guru membimbing siswa mengajukan prediksinya. Selanjutnya tahap observe. Pada tahap ini, siswa dibimbing oleh peneliti untuk melakukan kajian literasi dari buku paket kimia kelas XI IPA. Rata-rata siswa kesulitan dalam penentuan ion senama. selain itu siswa juga kurang dalam membedakan besaran nilai Qc dan ksp sehingga belum bisa menentukkan terbentuknya endapan atau tidak, serta keterbatasan alat hitung (kalkulator) membuat waktu siswa banyak terbuang. Tahap terakhir yaitu explain (menjelaskan). Pada tahap ini siswa akan menjalaskan hasil pada tahap observasi (kajian literasi) yang sudah dilaksanakan dan membandingkan hasilnya dengan prediksi awal siswa, apakah sesuai atau tidak. Pada tahap ini, beberapa kelompok ragu dengan jawabannya sehingga enggan untuk menyampaikan hasilnya, selain itu juga waktu yang tidak cukup membuat peneliti dan siswa hanya saling mencocokkan jawaban.

\section{Kelas Kontrol}

Kelas yang yang diterapkan model pembelajaran langsungtelah dilaksanakan sesuai tahapan yang ada, dengan penilaian keterlaksanaan observer terhadap peneliti pada setiap pertemuan. Model pembelajaran langsung yang diterapkan meliputi ceramah, diskusi dan tanya-jawab. Pembelajaran di kelas kontrol dirancang dengan pertemuan dan materi yang sama agar memudahkan peneliti mengamati hasil belajar dan pemahaman konsep siswa.Adapun hasil skor kemampuan pemahaman konsep kesetimbangan kelarutan siswa berdasarkan indikator kemampuan pemahaman konsep dapat dilihat berikut ini:

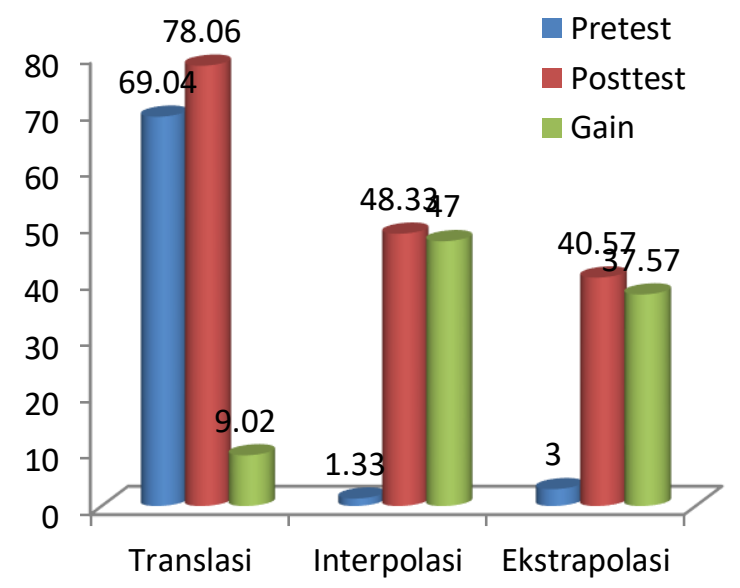

Gambar 3. Pemahaman Konsep Siswa Kelas Kontrol

Secara sederhana translasi menurut Bloom dalam Subiyanto (1988) adalah kemampuan untuk menerjemahkan suatu konsep ke bahasa yang dipahami sendiri kemudian 


\section{Chemistry Education Practice,1 (2), 2018 - 33}

Suhaesa, Andayani, Muti'ah, Anwar

ditunjukan dengan menyampaikan dalam bentuk lain berupa model atau simbol yang digunakan. Pemahaman konsep tingkat translasi ini mengalami peningkatan dari hasil pretest 69.04 $\%$ (kategori tinggi) menjadi $78.05 \%$ (kategori tinggi) setelah penerapan pembelajaran dikelas (posttest). Peningkatan ini tidak lebih baik dibandingkan dengan hasil pada kelas eksperimen.

Pertemuan pertama dikelas kontrol, dengan submateri konsep kelarutan dan hasil kali kelarutan (pertemuan pertama) dan pemamfaatan kesetimbangan kelarutan dalam kehidupan sehari-hari (pertemuan kelima) diawali oleh kegiatan pendahuluan penyampaian apersepsi, dibantu dengan Lembar Kerja Siswa (LKS), siswa secara berkelompok bekerja sama untuk menemukan jawaban dan mengambil keputusan penyelesaian masalah yang tepat. Di kelas kontrol pertemuan pertama ini,dirancang juga dengan adanya praktikum untuk melatih siswa menemukan konsep tentang kelarutan dan hasil kali kelarutan. Masalah yang dihadapi tidak jauh berbeda dengan yang dialami oleh kelas eksperimen. Siswa kebingungan karena sebelumnya belum pernah melalukan praktikum. Keterbatasan waktu mengharuskan peneliti dan siswa tidak bisa melakukan diskusi dan presentasi sehingga peneliti mengajak siswa untuk menyamakan kesimpulan.

Interpolasi adalah kemampuan untuk mengembangkan dan mendapatkan informasi yang tidak tercantum secara ekplisit dari sumber yang dirujuk. Satu tingkat lebih tinggi dari translasi yang hanya mengubah informasi yang didapatkan ke dalam bentuk lain, maka interpolasi mampu memberikan lebih dari yang tertuang secara eksplisit dan disampaikan. Pemahaman konsep tingkat interpolasi ini mengalami peningkatan dari hasil pretest $1,33 \%$ (kategori sangat rendah) menjadi $48.33 \%$ (kategori sedang) setelah penerapan pembelajaran di kelas (posttest). Peningkatan ini lebih baik dibandingkan dengan hasil pada kelas eksperimen. Salah satu faktor yang mempengaruhi hasil belajar siswa adalah motivasi."Motivasi adalah dorongan dasar yang menggerakan sesorang untuk bertingkah laku "(Hamzah B. Uno, 2008). adanya motivasi membuat siswa terdorong melakukan sesuatu untuk mencapai tujuan tertentu sehingga jika diaplikasikan dalam proses pembelajaran siswa akan belajar lebih keras, ulet, tekun, mempunyai rasa inigin tahu terhadap sesuatu dan memiliki konsentrasi dalam proses pembelajaran. Proses pembelajaranpeneliti sering mengulangkembali pelajaran sebelumnya terkait konsep kelarutan dan hasil kali kelarutan (pertemuan kedua) dan membahas pengaruh penambahan ion senama/sejenis dan pengaruh $p h$ (pertemuan ketiga). Selain dengan penjelasan, penyampaian materi juga diselangi dengan latihan soal. Pada pertemuan ini, hambatan yang sama juga dijumpai seperti dikelas eksperimen. Sebagian besar siswa masih belum bisa menuliskan persamaan reaksi dengan benar. Hal ini suatu kesalahan yang sangat vatal mengingat reaksi kimia adalah inti dari pelajaran kimia. Apabila siswa tidak bisa menuliskan reaksi kimia yang setara dan benar, dapat dipastikan ia akan mengalami kesulitan dalam mempelajari kimia. Sehingga peneliti mengulangkembali tentang reaksi kimia dan cara menuliskannya dengan benar. Selanjutnya siswa berlatih menghitung besarnya kelarutan dan hasil kali kelarutan.

Ekstrapolasi adalah kemampuan untuk meramalkan (menduga) atau memberikan gambaran akan sesuatu hal berdasarkan trend yang muncul pada data. Hal-hal yang diramalkan dapat berupa konsekuensi, implikasi dan akibat yang akan muncul berdasarkan motif dan pola-pola yang ada pada data. Hal ini berarti ektrapolasi lebih dari sekedar pemahaman mengenai hal-hal yang kongkret dan abstrak dari data yang didapatkan (Bloom dalam Subiyanto, 1998). Pemahaman konsep tingkat ekstrapolasi ini mengalami peningkatan dari hasil pretest $3 \%$ (kategori sangat rendah) menjadi 40,57\% (kategori sedang) setelah penerapan pembelajaran di kelas (posttest). Hal ini disebabkan karena siswa tidak mengetahui sama sekali tentang terbentuknya endapan pada saat pretest sehingga ketika posttest terlihat peningkatan secara signifikan, bahkan peningkatan ini lebih baik dibandingkan dengan hasil pada kelas eksperimen. Pertemuan keempat membahas pengaruh ion senama berupa terbentuknya endapan serta cara menentukannya melalui perhitungan. Pertemuan ini lebih banyak diisi dengan latihan soal yang sebelumnya guru memberikan contoh terlebih dahulu. Kelas kontrol terlihat aktif dan antusias. Guru juga senantiasa membantu siswa yang kesulitan dalam pembelajaran.

Mengetahui pengaruh model pembelajaran di kedua kelas, guru juga melakukan observasi aktivitas siswa. Berdasarkan data tambahan tersebut, kelas kontrol memiliki keaktifan yang lebih tinggi dari pada kelas eksperimen. Siswa-siswa kelas 


\section{Chemistry Education Practice,1 (2), 2018 - 34}

Suhaesa, Andayani, Muti'ah, Anwar

kontrol lebih antusias dan termotivasi dalam mengikuti pembelajaran. Melalui tahapan pembelajaran langsung siswa kelas kontrol memiliki sikap sosial, saling menghargai pendapat dalam diskusi dengan baik. Sementara siswa kelas eksperimen lebih pasif dalam proses pembelajaran berlangsung, tidak semua siswa terlibat dalam sesi explain (menjelaskan) yang diberikan guru, siswa-siswa yang berani mengeluarkan pendapat dan bertanya cenderung monoton. Hal ini dikarenakan siswa belum terbiasa dalam pembelajaran menggunakan model pembelajaran Predict-Observe-Explain (POE). Masalah lain yang dihadapi dalam pembelajaran yaitu siswa masih belum memahami materi-materi kimia sebelumnya, khususnya materi-materi yang ada kaitannya dengan kesetimbangan kelarutan seperti materi asam basa, $p \mathrm{H}$, dan penyetaraan reaksi, sehingga mau tidak mau guru akan mengulas kembali dan membuat waktu pelajaran terbuang sia-sia.

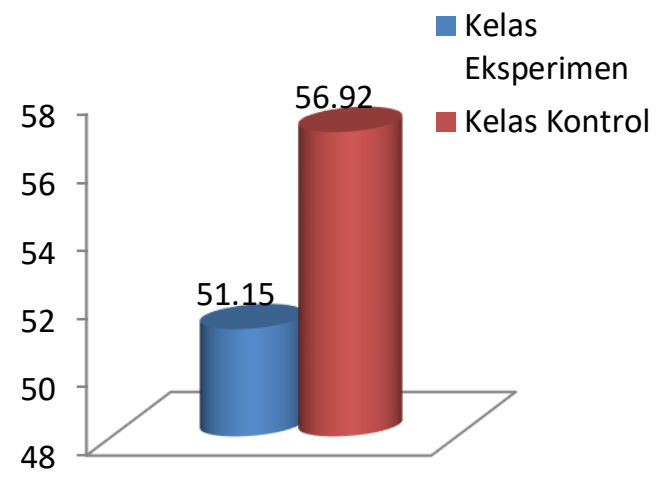

Gambar 4 Grafik Aktifitas Siswa

Selain itu, guru juga sebagai motivator dan pemberi arah kurang berperan maksimal. Peran guru yang seharusnya sebagai motivator adalah memotivasi siswa dan mendorong siswa agar selalu aktif meningkatkan kemampuan berpikir, memahami masalah serta dapat mempertanggungjawabkan hasil penemuannya. Sementara, tugas guru sebagai pemberi arah adalah seharusnya memberi arahan-arahan bernilai positif sehingga pembelajaran berjalan dengan baik sesuai tahapan model pembelajaran dan tujuan pembelajaran yang ingin dicapai.

Selain dengan gambaran pelaksanan pembelajaran di kelas, mengetahui ada atau tidaknya pengaruh model pembelajaran PredictObserve-Explain (POE) terhadap pemahaman konsep siswa, juga dilakukan pengujian hipotesis menggunakan ujin gain-t, yang mana menggunakan data selisih pretest dan posttest.
Pengolahan data uji hipotesis dihasilkan thitung yakni sebesar 1,39. Nilai $F_{\text {hitung dikonsultasikan }}$ dengan $F_{\text {tabel }}$ sebesar 2,00. Apabila $F_{\text {hitung }}<F_{\text {tabel }}$, maka Hipotesis nol (H0) diterima dan Hipotesis alternatif (Ha) ditolak. Berdasarkan pemaparan di atas, dapat dikatakan bahwa pembelajaran dengan menggunakan model Predict-ObserveExplain (POE) tidak berpengaruh terhadap pemahaman konsep siswa materi kesetimbangan kelarutan kelas XI MIA SMAN 2 Labuapi tahun ajaran 2017/2018.

\section{SIMPULAN}

Berdasarkan tujuan, analisis data, dan pembahasan maka dapat disimpulkan bahwa model pembelajaran Predict-Observe-Explain (POE) tidak berpengaruh terhadap pemahaman konsep siswa materi kesetimbangan kelarutan kelas XI MIA SMAN 2 Labuapi Tahun Ajaran 2017/2018.

\section{DAFTAR PUSTAKA}

Husain, R. H., S. Mulyani, \& Wiji. (2013). Pengembangan Representasi Kimia Sekolah Berbasis Intertekstual Pada Submateri Teori Atom Dalton Dalam Bentuk Multimedia Pembelajaran. Jurnal Riset dan Praktik Pendidikan Kimia. 55(1).

Liew, C.W. 2004. The Effectiveness of Predict, Observe, Explain Technique In Diagnosing Student's Of Science and Identifying Their Level Of Achievement. (Online). Tersedia : http://adt.curtin.edu.au/theses/avaiable/a dtWCU20050228.145638/unrestricted/0 1Front.Pdf (25 Oktober 2018).

Musbhirah, Q. U., Muntari, Al-Idrus, S.W. 2018. Pengaruh Model Pembelajaran Joyful Learning dengan Media Kartu Aksi Terhadap Hasil Belajar Kimia Materi Koloid Pada Siswa Kelasxi MIA MAN 2 Model Mataram. Chemistry Education Practice, 1 (1): 26-33.

Nuramelia. 2016. Pengaruh Model PembelajaranPOE (Predict-observeExplain) Terhadap Keterampilan Proses Sains Siswa Pada Konsep Sistem Pencernaan. Jakarta. Universitas Islam Negeri Syarif HidayatullahJakarta. Skripsi. Tidak Dipublikasi.

Ozdemir, H. (2011). Effect of Laboratory Activities Designed Based on Prediction, Observation, Explanation 


\section{Chemistry Education Practice,1 (2), 2018 - 35}

Suhaesa, Andayani, Muti'ah, Anwar

(POE) Strategy on Pre Service Science Teachers' Understanding of Acid-Base Subject. Western Anatolia Journal of Educational Science: 169-174.

Sa'ud, Udin. (2011). Inovasi pendidikan. Bandung: Alfabeta.

Subiyanto. (1998). Evaluasi Pendidikan Ilmu Pengetahuan Alam. Jakarta. Direktorat Jendral Pendidikan Tinggi.

Sugiyono. 2014. Metode penelitian Kuantitatif, Kuantitatif dan $R \quad \& D \quad$. Bandung: Alfabeta.

Suyono, dan Hariyanto. 2012. Belajar dan Pembelajaran Teori dan Konsep Dasar. Bandung. PT Remaja Rosdakarya

Uno, Hamzah B. 2007. Teori Motivasi dan Pengukurannya. Jakarta. Bumi Aksara.

Widiadnyana, I.W,dkk. 2014. Pengaruh Model Discovery Learning Terhadap Pemahaman Konsep IPA dan Sikap
Ilmiah Siswa SMP. Journal Program Pascasarjana Universitas Pendidikan Ganesha Program Studi IPA. Singaraja. Vol 4 (2).

Winarti, A. (2001). Pembelajaran Ilmu Kimia dan Kontribusinya Terhadap Perkembangan Intelektual. Jurnal Vidya Karya XIX. Malang. (2). 109-115.

Yupani, Garminah, dan Mahadewi. 2013. "Pengaruh Model Pembelajaran PredictObserve-Explain (POE) Berbantuan Materi Bermuatan Kearifan Lokal terhadap Hasil Belajar IPA Siswa Kelas IV". Laporan Penelitian Universitas Pendidikan Ganesha. 